\title{
Research on the Brand Image Building Route and Mechanism of Pop-up Store
}

\author{
Geng Huang ${ }^{1}$ \\ Donghua University \\ Tongji University Shanghai Institute of Design and \\ Innovation \\ Shanghai, China \\ hw_1209@126.com
}

\author{
Xinqun Feng ${ }^{2 *}$ \\ Donghua University \\ Tongji University Shanghai Institute of Design and \\ Innovation \\ Shanghai, China \\ 451496289@qq.com
}

\begin{abstract}
In this paper, the author studies the corresponding mechanism of "flash" and brand image building from the perspective of "flash" marketing motivation and consumption mode. Through the analysis of the mechanism of the diversity of Pop-up Store flash store brand involved, which extends out the relationship between sustainable dissemination of short-term sales and brand value of the flash store, process, combing out flash success factors of marketing, finally realize the effective customer perception of the brand, expanding the spread of brand value.
\end{abstract}

\section{Keywords-Pop-up Store; Flash; Brand; Valid perception}

\section{INTRODUCTION}

The business of global retail industry is now experiencing huge pressure, such as the high homogenization competition, the commercial catalyst, the aesthetic fatigue of consumers, the impact of network consumption on real stores, the fast updating of information and the consumption updating as well as the decrease in people's traditional loyalty for brand. Consumption has showed a gradual tendency towards individuals, and in order to seek the "freshness" degree of brand, people hope to enjoy the product within a shorter period. In 2016 New York Fashion Week and London Fashion Week, the service brands mostly pushed out the mode of "simultaneous watching and purchasing", fully shortened the zero distance between the show field and the sales, and became a new reform. Along with the constant increase in consumer's experience demand, the gradual exploration of retail commerce can stimulate the brand sales and image innovation mode, and meanwhile, import art, culture, tourism, scientific elements, fashion life and other new elements, and enlarge the supply of consumption contents in sprits and interaction layer and the fast reaction. Pop-up Store has fast become the world's popular commercial mode. The "flash" mode has flexible maneuverability, and has even surpassed the range of commercial retail. In the period of digitization transmission, operation can be hard for traditional publishers, but along with the short-term effect of hot politics and social activities, "fast" newspaper has emerged at the right moment, for instance, in British, the New European published by Arch ant as per $48 \%$ of British votes about Brexit was merely set for a minority of people and fixed topic. Along with the heat of Brexit being faded away, this newspaper will also disappear naturally [1].

The effectiveness for the commercial mode of flash is huge, and the meaningful evaluation about the mode and attraction of Pop-up Store should understand the extent to utilize the brand image design and customer behavior, to stick the existing groups and find new target groups; in the previous researches, lots of them analyzed the commercial mode, product supply chain, consumer psychology and other aspects, and neglected the difference between the space image of traditional brand and the brand image design of Pop-up Store as well as the "flash" experience, and the potential value for the conveying strategy of brand image space. This research is aimed to analyze the brand image design and transmission method under the commercial mode of Pop-up Store, and then sort out the brand space transmission objective and mode of action for the Pop-up Store from the perspective of consumer psychology, visual marketing, interaction and other aspects, and then help the readers to have a deeper understanding on the brand image building and the corresponding strategies in the new transmission mode.

\section{THE COUPLING OF "FLASH” AND COMMERCIAL MODE}

\section{A. Definition of concept}

"Flash" is a kind of short behavior act. It is used to describe fast response and emergencies, and then arouse people's high attention. The representative event is the sudden gathering of more than 500 people at the Manhattan Plaza, New York, America in 2003, to simultaneously worship one mechanical dinosaur; after 5 minutes, all people rapidly dissolved. "Flash" is connected with brand marketing, implements the operation within a short time, and has become a popular and fashionable commercial mode that relies on temporary stores that arouse attention through creative practice. At present, consumers pay more attention to the sensory stimulation and interaction brought by brand experience, while the concept of flash can exactly arouse the curious emotional experience of consumers.

The cooperation of "flash" and brands has created Pop-up Store, or the brand experience "guerrilla". The born motivation is originated from American Flash Mob, and is also quite similar to the "Pop-up Windows" on the internet. Although 
"Pop-up Store" has been widely applied in marketing practice, there is no unified definition. Uniqueness, transience, virtual marketing, creativity, etc. have constituted some imaginary and fragment vocabularies. The business hours for these stores are varied from several days to one year.

\section{B. "Flash" and brand marketing motivation}

The mission of "flash" is to create surprises to attract clients, and this coincides with the brand marketing means. It is originated from America and specific to entrepreneurs who haven't found their own target clients, and don't have enough funds to open a store in flourishing regions. They can utilize the publicity mode of Pop-up Store to arouse attention, and meanwhile, have no need to spend too much money; this is the initial mode for the Pop-up Store to exploit the market. In Japan, Rei Kawakubo, the Fashion Godfather used this method in its own brand-Comme des Garcons in 2004, transformed one old bookstore in Berlin, and obtained a huge success in sales for one year; in the later periods, it was widely promoted by the fashion circle. This new commercial mode is very effective in sales and brand publicity [2].

Through more than ten years of development, "flash" is no longer the marketing tool used to attract people's attention, instead, it has become a promoter for the brand to go deeper into the consumers. At present, the main brands have adopted or plan to adopt such "guerrilla" mode to gain consumers' attentions and meanwhile, expand the popularity of its brand. The Pop-up Store is temporary and the objective thereof is to provide exciting brand experience to consumers and then through unique store concept, and enjoyable commercial atmosphere, it is aimed to provide value-added shopping value; the Pop-up Store emphasizes on consumers' experience, rather than the sales of more products, and the objective of arousing public praise is to get new target groups. For instance, in 2013, Hermes organized one Pop-up Store activity in New York, and merely opened for 4 weeks, during which it had not only promoted the new products, but also set a mini-golf course in the publicity area, so as to reinforce the design and fashion life label of Hermes [3].

\section{Consumption experience and transmission updating:}

The basis for the occurrence of Pop-up Store is incurred by the transformation of consumption upgrading and consumption mode, and the transmission and service of social information also promoted the transformation of Pop-up Store [4]. The development of internet information has largely changed people's living and consumption mode in transmission mode and strength, and each person can become the information transmitter; in 1898, Lewis from America put forward the AIDMA research mode specific to the consumers, and along with the upgrading of new media environment, Dentsu Group put forward AISAS new consumption mode, and reinforced sand clock type consumption behavior; this had realized the transmission of brand reputation through the network information on social contact media platform after the consumption behavior, and then stimulated the consumption behavior of consumers. All of these have infinitely enlarged the short-term behaviors, such as 'flash' activities on the social contact platform, and consumers can constantly overlay the reputation and brand image, and then make the short-term sales of Pop-up Store become long-term reputation and impression; the Pop-up Store can constantly overlay the "freshness" degree of brand on the social contact platform through gaining theoretical transmission and reputation. In 2016, Hong Kong was subject to weather, society and other factors of influence, and the severe winter of the retail industry has continued for a very long time; in 2016, the overall sales volume of retail industry in Hong Kong was decreased by $10.1 \%$ on a year-onyear basis. To attract more mainland tourists, the government and merchants have enlarged the publicity strength and played the advantages of the Pop-up Store and social contact platform. Kitty, the Principal for the retail business of Hysan Development Company Limited said that, the company is located at Hysan Place, Causeway Bay, a tourist attraction, and has released the flash space of Nike, Kishl's, Uniqlo and other brands, and it was used to fast expand social influence and attraction, and drive the mainland tourists to come to Hong Hong for shopping. Besides, Lululemon Sports Equipment Company also published Sunday morning yoga course in the public area, and overturned the continuous decrease in the retail industry of Hong Kong. The updating of AISAS consumption period and consumption scale has also stimulated the mode copying of Pop-up Store, and made the brand store marketing strategy incline towards the bottom of the sand clock, and finally planted the brand concept and then obtained the sales result [5]. 


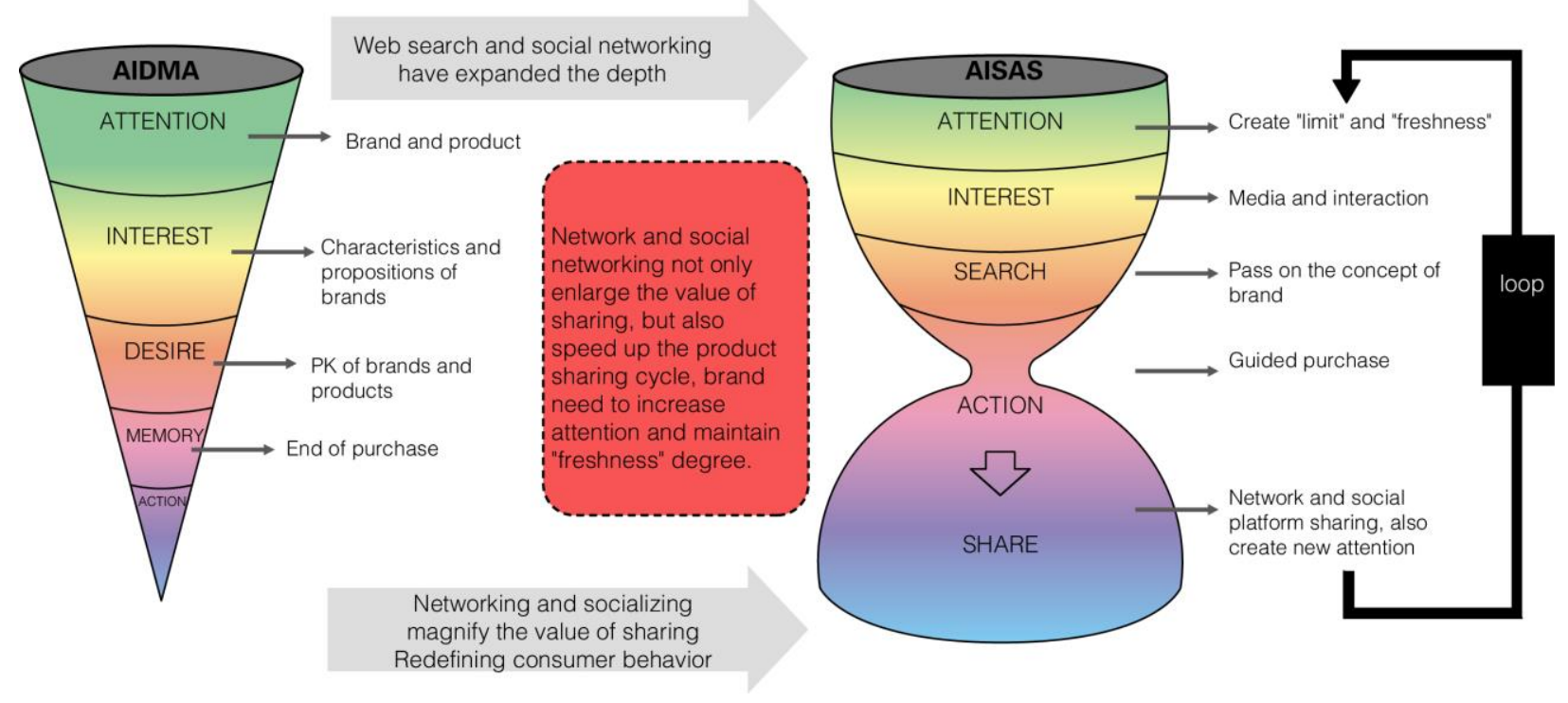

Fig. 1. AISAS Consumption Period and Mode (Picture Source: Drawn by the Author)

\section{THE DIVERSIFIED MECHANISM OF "FlaSh"}

Different brands select Pop-up Store for different objectives, so rich guerrilla themes will be generated, with various interference modes. It can help the brands for monitories of designers to popularize brand awareness, and also build up momentum, conduct preheating and test for fashionable brands to enter into a brand new market. For luxuries, this is a downto-earth marketing mode close to the public. Chanel used to place a slot vending machine at a store company in London, and the customers need to purchase and make payment through the mode of inserting coins. As per the "flash" guerrilla mode, the brand marketing strategy can be mainly reflected in time restriction, conceptual innovation, free location, interaction and other types.

(1) Time restriction (informal): "these stores silently occur in the group, and then disappear or transform very fast, bringing freshness and surprises to the retail industry", described by the trend research company-Trendwatching about the rising trend of Pop-up Store. Time restriction is the most basic characteristic of Pop-up Store, and since the time of guerrilla is different from the long-term operated store, from the perspective of marketing and psychology, time can keep the freshness degree of products, and meanwhile, bring the sense of urgency. The most common mode is to temporarily build the space guerrilla mode, occupy partial spaces of large-scale business or buildings, and adopt the leasing mode to form a temporary area, etc.; generally, it will display the new products of the brand in the current season, and form more interactions with consumers, publicize the new products of the brand, and meanwhile, take this opportunity to collect the data about the target group. Currently, Hermes and other international firstline luscious brands often select the top-end cities of fashion to open such guerrilla store, and the attention attracted by themselves along with the sales strategy of "restricted time" can make Pop-up Store fast become the new type of operation for your retail, and for some brands, they even merely open such Pop-up Store at areas gathering young fashion at the initial period of the operation. The Pop-up Store of TOP SHOP in Shenzhen merely planned for two months, but the sales volume reached to USD 10,000, and it hasn't opened any real brand store yet.

(2) Concept innovation (friendly): brand concept is a good guerrilla mode; it adopts the mode of display and exhibition to adapt to the site form and scale, and generally, it adopts the means of art to metaphorically interpret the brand concept, and then take this opportunity to publicize the connotation of brand. For instance, in 2017 Shanghai Designing Activities, "ROBAM" brand occupied a very big space to publicize its own ecological kitchen concept, but it didn't take this opportunity to display its own new products like what other brands did, instead, it made its own exhibition place into a contemporary art exhibition activity, and then cooperated with From Yuhangrong Design Library, and Longwu Water Source Protection Team, invited designers to teach the local peasants' metal knit art, so as to revitalize the local economy, and decrease the ecological pollution that will be brought by bamboo weaving, and then from the perspective of social ecological responsibilities, it had also transmitted that "ROBAM" brand not only focused on design aesthetics, but also the ecological responsibilities (Figure).

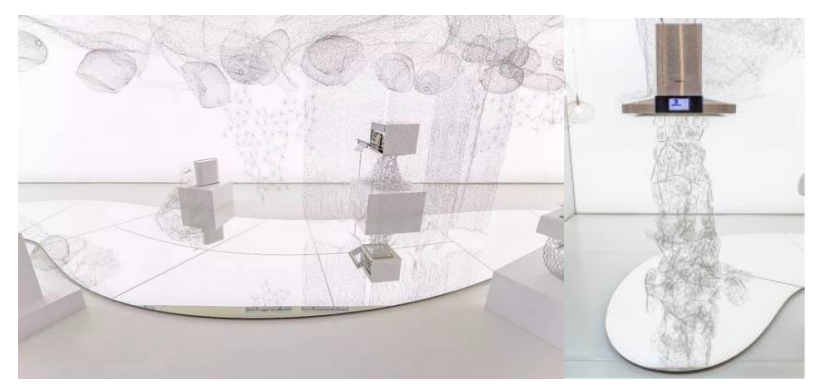

Fig. 2. Art Concept of "ROBAM" in Shanghai Designing Activities 
(3) Free location (barrier-free): the Pop-up Store is not restricted by location, and it is only related to the concept transmitted by the brand, and the location of guerrilla can be set as per the gathering area of target consumers, so the exhibition mode and place are very free and bold. H\&M opened the Pop-up Store at Scheveningen Beach, Hague, Holland [6].

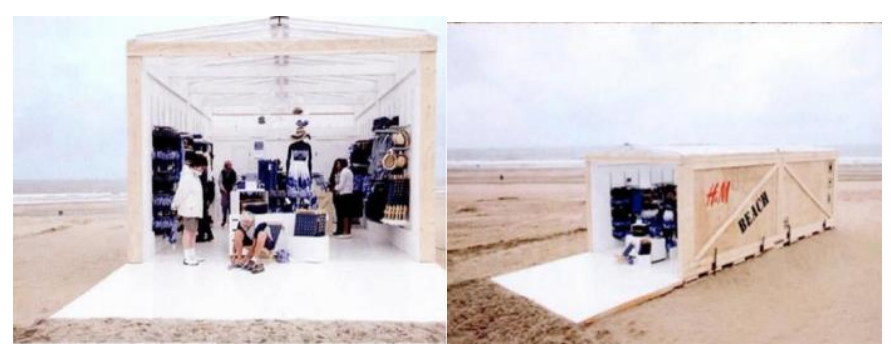

Fig. 3. H\&M Pop-up Store

(4) Interactive (games): the mode of creating events for interactive guerrilla is also the most popular mode in the fashion circle; it creates events within a short time, and then attracts the target group of the brand, and expands the brand heat degree and consumer viscosity. For instance, in 2009, NPC opened the first store in Shanghai, and then after 8 years, before the demolition and redecoration of the brand store, a cross-boundary art exhibition was held here, Zhu Jingyi, the Contemporary Artist used calligraphy and graffiti-art to freely express the art concept of fashion inside the store space, and merely in the two-day activity, NPC street culture and young fashion had gathered many fans through the mode of art.

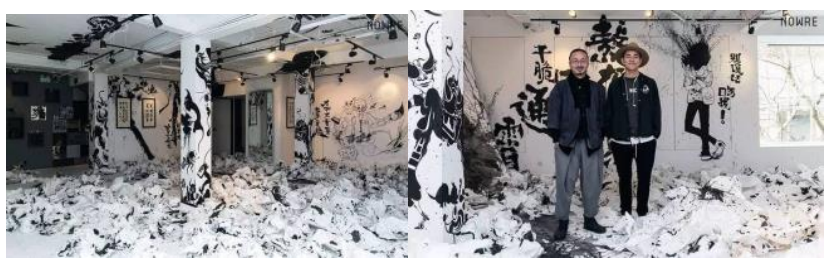

Fig. 4. Zhu Jingyi (the Contemporary Artist) and NPC Cooperated and Trans-boundary Art Exhibition

\section{THE SHORT-TERM EFFECT AND VALUE CONTINUITY OF "POP- UP" STORE}

Pop-up Store can create surprises in vision and then attract the target consumption group, and reinforce the brand experience. But since the period is too short, Pop-up Store mostly creates short-term values, and the creation of short-term marketing activities also requests the integration of lots of manpower and financial resources. For some designer brands at the initial period of the design, if the only objective is to gain the attraction of consumers, short-term mechanism must be non-persistent. In the field of marketing, short consumption experience is almost nonexistent, and through collecting these methods, the continuation of short-term value for Pop-up Store can be reflected in several aspects as follows:
(1) Full-channel sales; more and more enterprises are now using full-channel retail mode, and it can not only realize the online sales, but also open brand store, and meanwhile, add the mode of brand guerilla to expand influence. For instance, one MIT report called Super Shopping Cart pointed out that, along with the updating of consumption habits, consumers utilized several platforms and modes for shopping, and the Pop-up Store had obviously become a very important and necessary supplementation of brand store. Along with the decrease in online flow bonus, more and more online service brands transferred their view to the offline, and regarded the Pop-up Store as the start of offline trial. The Pop-up Store can form closed brand line, and the online can exert promotion effect for brand publicity, and then bring passenger flow for offline stores; the offline can bring good experience to consumers, and increase the online store flow. As the newly rising online underwear brand in the recent years, ADORE ME utilizes Pop-up Store to conduct $\mathrm{O} 2 \mathrm{O}$ attempt, and has obtained a big success. Consumers can book online and go to the Pop-up Store to experience the customized service brought by the experts [7].

(2) Consumption cooperation; since consumers have target tendency when shopping, brands can adopt the mode of mutual implantation to conduct product guerrilla, for instance, one jewelry store can cooperate with flower store or chocolate store workshop, and open one Pop-up Store specific to the Valentine's Day, and let consumers obtain peasant sensation in the store.

(3) Test new products and concept, Pop-up Store has become the tool for marketing research. If a good idea can be hatched within the limited time and area, Pop-up Store is a very good platform; it can let merchants show their own products to consumers, and obtain the feedback data and suggestions of consumers through this platform before comprehensively marching towards the market; currently, Google is utilizing Pop-up Store to test the new product and new concept. Old Navy, the cloth brand subordinated to GAP also played this mode this year. After obtaining $2,000 \mathrm{~m} 2$ area of store in Shanghai, it didn't publically announce the sales of Logo shirt and jeans; instead, it played the Pop-up Store. GAP took this opportunity to collect the big data of consumers, explore the market conditions, and open a road for brand marketing. Small retailers can also use this mode to attract more customers, and even adopt the mode of giving gift cards to create a reason for customers to consume in the brand store afterwards.

(4) Search for new income flow. The time for Pop-up Store is limited, and will cause a sense of urgency to people, so it will generally promote the sales volume, but some of them will be converted to a big amount of purchasing. Anton Commissaris, the CEO of Vend Company (the retail outlet system server) in North America pointed out that, such abnormal shopping environment would bring more incomes, or use a brand new mode to show the inventory to consumers. For instance, a clothing store can fully conduct the reduction sale of inventories for the current season at a strange area, and these styles can be immediately turned into new styles for different consumption groups. 


\section{V. "FLASH” AND BRAND IMAGE BUILDING ROUTE (SUCCESSFUL FACTORS AND VALID PERCEPTION)}

The value of Pop-up Store should be finally reflected in the brand image building objective, so it is very necessary to analyze the brand image from the perspective of process and psychological perception, valid and perfect procedures are the basis for the existence of Pop-up Store, and the establishment of complete and valid brand perception is the mission of Popup Store.

The successful factors of Pop-up Store should be analyzed through building the brand core and procedures in the same space. To create a successful flash marketing, it is requested to coordinate many factors to conclude consensus brand strategy, and build brand "freshness" degree in short-term flash marketing, and realize the transmission appreciation of enterprise brand core in the long-term strategy, and only when the short-term and long-term strategies are well balanced, the marketing value of Pop-up Store can be reflected. Through analyzing the flat procedures, Pop-up Store includes address selection, store design, budget, limited products, valid performance and interaction, customer feelings or inspiration, virus transmission, target market, enterprise team, brand identification, brand story, enterprise culture, and skills. In the setup of each procedure element, the brand core of enterprises should be reflected, so as to realize the success in building brand image, otherwise flash will be nothing but a flash in the pan, and become the temporary stall of discount.

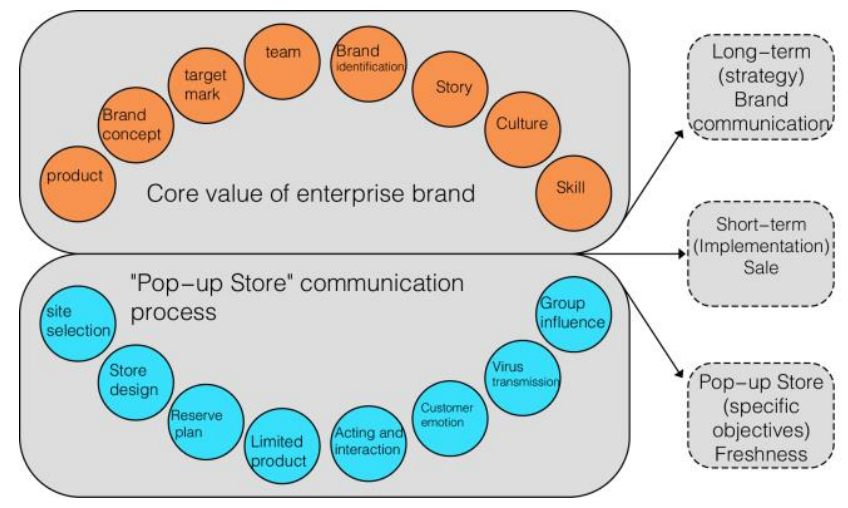

Fig. 5. Successful Factors of Pop-up Store

Except for possessing successful factors, the analysis of customers' perceptions from the perspective of psychology and valid feedback are the key of AISAS marketing, and it is very complicated to build a valid perception of customers. Here, we need to build a comprehensive framework model of threedimensional consumption psychology, and this model has distinguished three layers of valid perceptions (brand perception, user perception, and social perception) and five brand perception factors (identification, experience, integration, symbol and connection). Meanwhile, it can understand the different depths and effects of perception in the building of brand image from social layer, individual layer, and brand layer.
In the fast perception process for consumers, unified brand image will be penetrated into different perception layers through five aspects, and adapt to different modes of marketing intersection. This mode is the basic opinions and judgment process of consumers for the brand, and also the mental model for the perception of one brand; in the model, you can see that the identification of one brand can design various products and product varieties, and the experience of brand perception is conveyed through culture; finally, consumers can form a joint consumption group through centering on the brand. The consumers can perceive and experience the characteristics of these brands. The structure of the model can also reflect the different degrees of brand psychology participation degree of consumers, for different demands of motivations and objectives can participate in three layers of the model. The most inner representative objective is the center, and it is the participation perception driven by function, and the consumers can distinctively obtain the brand information. The middle layer is the self-centered participation, and brand perception is the action and self-related consumption. The most outer representative is the social participation and brand, and it is the brand perception from the perspective of social culture, with group awareness. From the inner ring to the outer, the depth of brand perception will become more and more meaningful [8].

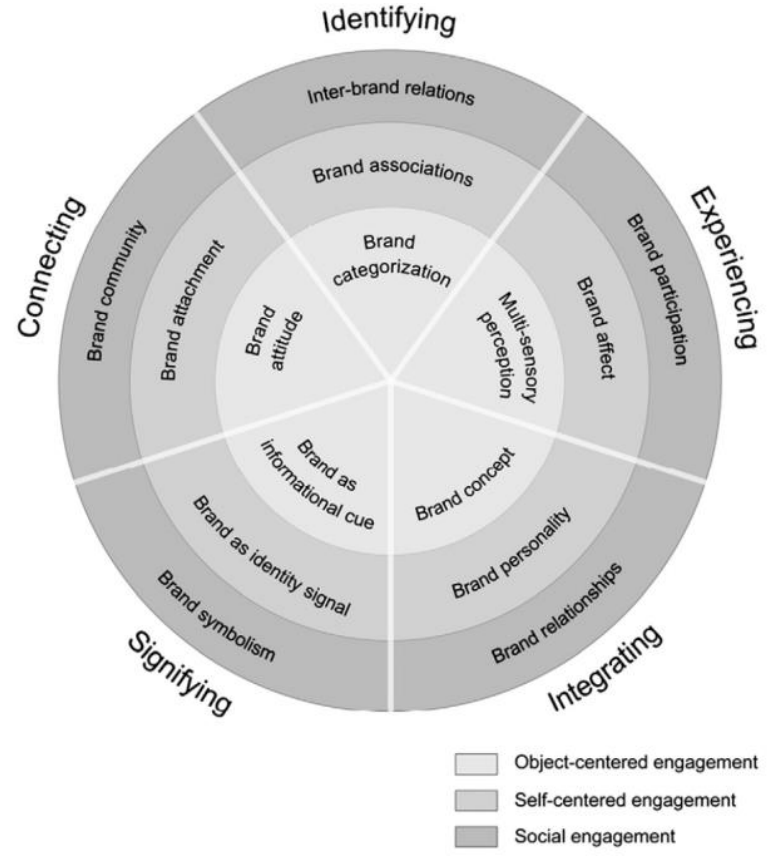

Fig. 6. Valid Perception Level of Brand

The route built by the aforementioned two brands should be reflected in the entire process and system of flash marketing, and it can not only create more specific transmission objective, and provide diversified and rich form, but also understand the short-term value of flash from the perspective of a continuous brand transmission. 


\section{CONCLUSION}

Through above ten years of transition, many brands have realized that, retail stores adopting "flash" mode can not only bring more sales volumes, but also let the brands further understand the customers, brand evolutionary process, and its influenced people. Pop-up Store has become one valid marketing method for various brands in the transmission process, and has ushered in fast-fashion development, and promoted fast brand industrial chain mode. The relationship between brand and consumers is not centered on sales, and it mostly provides a space for consumers to experience and perceive products, and brands. This paper conducts a systematic analysis on the mode of the Pop-up Store from the perspectives of the diversified modes of Pop-up Store, the continuity of short-term value, the successful factors of flash, and the perception depth, etc., so as to build the brand framework model of flash marketing model. As per the RET research report data, before 2012, Pop-up Store was under the emerging period in China, and from 2012 to 2014, it was under the startup period, and then from 2015, it had entered into a fast development phase, with above $100 \%$ of annual average compound growth rate; it is expected that in 2020, there will be above 3,000 Pop-up Stores in China. In the future, the combination of Pop-up Store with art museum, and theme block will become a new trend [9].

After several rounds of "flash" for various brands, consumers also become quite tired of such sales mode, and gradually short of the previous surprise and interest. The "freshness" of the motivation generated by Pop-up Store, and the consumption transmission updating have been evolving, and except for gaining the attention of consumers and implementing innovative coping in the short-term effect of enterprises, the most important thing is to return to the key point of marketing, and integrate the thought held by Professor Don Schultz, the Pioneer of marketing theory that the key point for the brand transmission plan objective is in "brandcustomer" relationship. One brand cannot attract consumers for a long time merely through gaining the "freshness" degree, and it is requested to deeply study the brand connotation, hommization, socialization, localization, globalization context, and globalization context, so as to practically meet the customers' demand, and obtain valid strategy and constant development. In the future, the Pop-up Store can be regarded as a brand transmission mode to study, and the individual consumers' target perception or marketing system integrated operation can be deeply studied, so as to build a perfect and three-dimensional flash brand transmission model, and let the retail industry obtain huge reference interests.

\section{REFERENCES}

[1] Nicola Clark, Translated by Li Xiaoyuan. Flash Newspaper Obtained Big Success in British [J]. China Business News, 2016, 58-59.

[2] Access to the luxury brand myth in pop-up stores: A netnographic and semiotic analysisOriginal Research Article.Journal of Retailing and Consumer Services, Volume 21, Issue 1, January 2014, Pages 61-68

[3] Linking pop-up brand stores to brand experience and word of mouth: The case of luxury retail[J]. Jan F. Klein,TomasFalk,Franz-Rudolf Esch,AlexeiGloukhovtsev. Journal of Business Research.

[4] E. Arnould, C. Thompson,Consumer Culture Theory (CCT): twenty years of research,Journal of Consumer Research, 31 (1) (2005), pp. 868882.

[5] Min Zhoumin. Pop-up Store Occurred in Hong Kong [J]. Shanghai \& Hong Kong Economy, 2016, (10):52-53.

[6] Lin Da. How Does "Pop-up Store" Play New Tricks? [J]. Successful Marketing, 2015, (11): 46-47.

[7] Zhang Mengru, and Sun Hong. The Marketing Strategy of Pop-up Store in Cloth Retail [J]. Modern Decoration, 2016, (09):245.

[8] B. Schmitt, The consumer psychology of brands. Journal of Consumer Psychology, 22 (1) (2012), pp. 7-17.

[9] Zhou Xuesong. Why Can Pop-up Store Realize Fast Growth in China [N]. China Economic Times, 2017-01-18 (006). 